\title{
Evolution of the Indian Monsoon System and Himalayan-Tibetan Plateau uplift during the Neogene
}

\author{
Anil K Gupta \\ Department of Geology and Geophysics, Indian Institute of Technology \\ Kharagpur - 721 302, INDIA \\ E-mail:anilg@gg.iitkgp.ernet.in
}

The Indian monsoon also known as the South Asian monsoon is an important feature of the climate system, marked by seasonal reversals in the wind direction with southwesterly winds in summer and northeasterly winds in winter. The summer monsoon plays an important role in global hydrological and carbon cycles, and affects climate and societies over a large part of Asia between $35^{\circ} \mathrm{N}$ and $10^{\circ} \mathrm{S}$. The monsoon is the lifeline to the people of Asia as region's food production and water supply are largely dependent on the summer monsoon rains. Thus the Indian monsoon constitutes a critical resource for the region's largely agrarian economies.

Considerable efforts have been made toward high resolution (high density sampling of the marine cores) reconstruction of proxy records of monsoon that have helped in the understanding of monsoon evolution, its variability over various time scales, and forcing factors that drive the monsoon on orbital and sub-orbital time scales. However, there are still unresolved questions as to the timing of the advent of the modern monsoon and driving mechanisms of monsoon variability. The elevated heat source of the Himalayas and the Tibetan Plateau is of vital importance for the establishment and maintenance of the Indian summer monsoon circulation through mechanical and thermal factors.
But there are different propositions about the attainment of the critical elevation by the Himalayas and the Tibetan Plateau to drive the Indian monsoon, ranging from 35 to $7.5 \mathrm{Ma}$ (Table 1). While the marine records indicate a major shift in the monsoon system between 9 and $8 \mathrm{Ma}$, the continental records suggest a range from 22 to $7.5 \mathrm{Ma}$ during which time the monsoon may have evolved. The model studies, on the other hand, put the origin farther back in time at $\sim 35 \mathrm{Ma}$. Recent study from China suggests a wet phase in the early Miocene and beginning of an arid phase (weakening of the summer monsoon) across 13-11 Ma (Hanchao et al. 2008). Thus to resolve these issues, a coordinated effort is required to analyze and compare high resolution records from marine cores from high sedimentation areas of the Arabian Sea and the Bay of Bengal as well as continental records of continuity.

\section{References}

Gupta AK, RK Singh, E Thomas and S Joseph. 2004. Indian Ocean highproductivity Event (10-8 Ma): Linked to Global Cooling or to the Initiation of the Indian Monsoons? Geology 32: 753-756

Hanchao J, J Ji and Z Ding. 2008. Cooling-driven climate change at 12$11 \mathrm{Ma}$ : multiproxy records from a long fluviolacustrine sequence at Guyuan, Ningxia, China. Palaeo3 In press

\section{TABLE 1. Evidence and timing of the Himalayan Uplift and Monsoon Intensification (Modified from Gupta et al. 2004}

\begin{tabular}{|c|c|c|c|}
\hline SOURCE & TYPE OF EVIDENCE & EVENT & TIMING (MA) \\
\hline Rowley and Currie 2006 & Oxygen isotope & Tibetan Plateau & 35 \\
\hline Ramstein et al. 1997 & Modeling & Monsoons and Paratethys retreat & $\sim 30$ \\
\hline Guo et al. 2002 & China loess deposits & Monsoon climate & 22 \\
\hline Wang 1990 & Sediments in China & Monsoons & 20 \\
\hline Clift and Gaedicke 2002 & Indus Fan sediments & Erosion and weathering & $\sim 16$ \\
\hline Clift et al. 2002 & South China Sea smectite mineral & Precipitation and monsoons & $\sim 15.5$ \\
\hline Spicer et al. 2003 & Fossil flora & Himalayan elevation and monsoons & خ્ર5 \\
\hline Coleman and Hodges 1995 & Tectonics & Himalayan elevation & $\nearrow_{14}$ \\
\hline Blisniuk et al. 2001 & Tectonics & Himalayan uplift and monsoons & $\lambda_{14}$ \\
\hline Chen et al. 2003 & Oceanic microfossils & Monsoons and upwelling & $12-11$ \\
\hline Dettman et al. 2001 & Isotopes and land & Monsoons & $\sim 10.7$ \\
\hline An et al. 2001 & Land and marine sediments & Uplift and onset of monsoons & $9-8$ \\
\hline Kroon et al. 1991 & Oceanic microfossils & Monsoons and upwelling & 8.6 \\
\hline Filipelli 1997 & Weathering and sediments & Monsoons & $\sim 8$ \\
\hline Quade et al. 1989 & Isotopes and flora & Monsoons & $8-7.6$ \\
\hline
\end{tabular}

